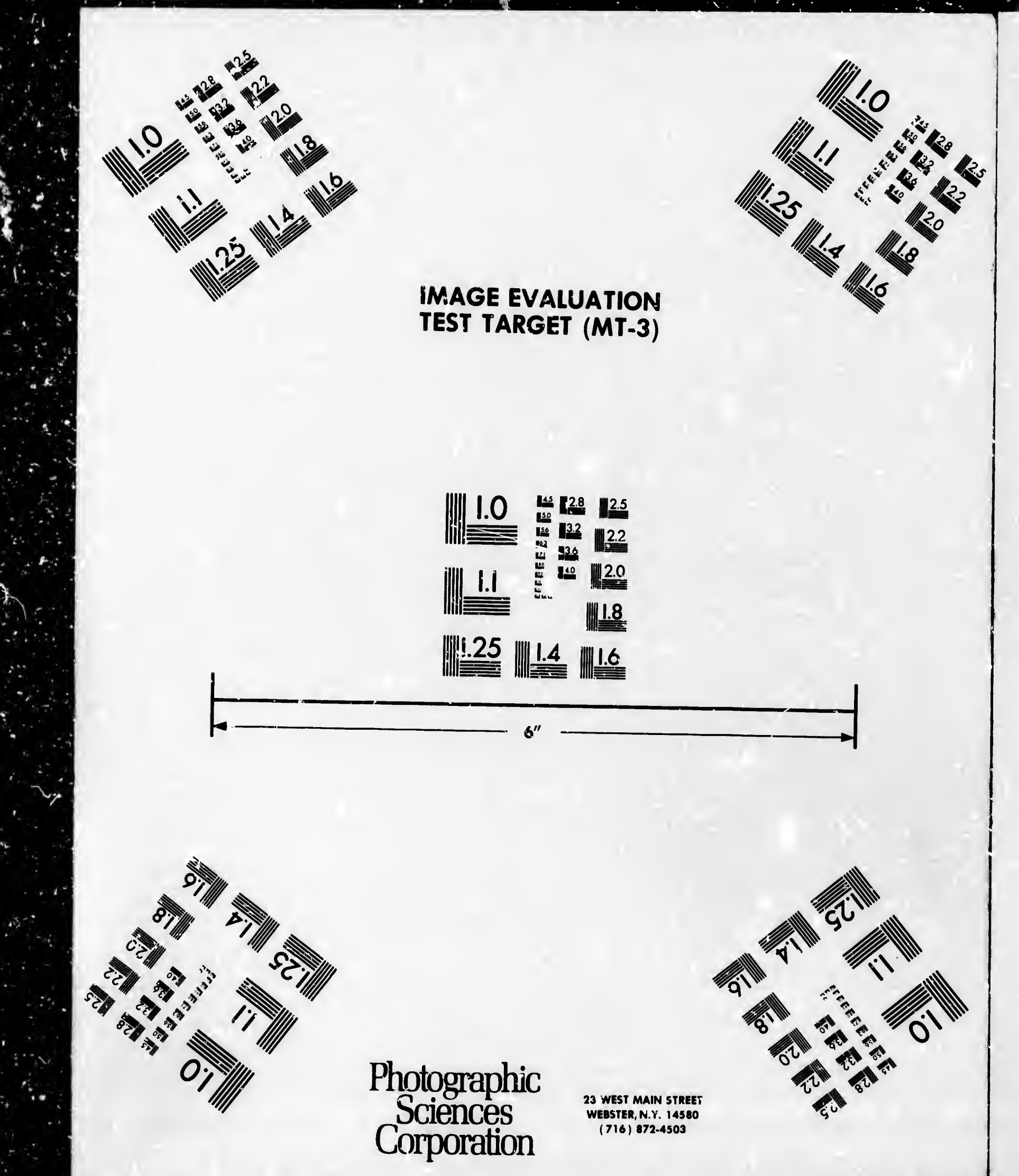



The Institute has nttempted to obtain the best original copy avallable for fliming. Features of this copy which may be blbliographically uniqua, which may alter any of the images in the reproduction, or which may signiflcently change the usual mothud of filming, are checked bolow.

Coluured covers/

Couverture de coulour

\section{Covers damaged/}

Couverture endommagbe

Covers reatorad and/or laminated/

Couverture restaurbe et/ou pelliculbe

Cover title missing/

Le titre de couverture manque

Coloured meps/

Cartes góographiques en couleur

Coloured ink (i.e. other than blue or black)!

Encre de couleur (i.e. autre que bleue ou noire)

Coloured plates and/or illustrations/

Plenches ot/ou illusirations on coulour

Bound with other material/

Relic avec d'autrea documents

Tight binding may cause shadows or distortion along intarior margin/

La reliure serrée pout causer de l'ombra ou de la distortion le long de la marge intórieure

Blank leeves added during restoration may appear winhin the text. Whanever possible, thesd have been omitted from filming/

II se peut que certaines pages blanches ajoutses lors d'une reatauration apparaicsent dans le texte, mais, lorsque cela stait possible, ces pages n'ont pas été filmóes.

Additional comments:/

Commentairea supplómentaires:
L'Institut a microfilmb le mellleur oxemplaire qu'il lui a 6t6 possible de se procurer. Les distails de cet exemplalre qui sorit peut-Ctre uniques du point de vue blbllogrephique, qui peuvent modifler une image reproduite, ou qui peuvent axiger une niodification dans la methode riormale de filmage sont indiqués ri-dessous.

Coloured pagea/

Pages de coisleur

Pages damaged/

Pages andommagóes

Peges restcred and/or laminatad/

Pagus reataurbes ot/ou polliculces

Pages discoloured, stained or foxed/

Paces décoloreses, tachetbes ou piquées

Peges detach6d/

Pages détach6es

\section{Showthrough/}

Transparence

Qcality of print varies/

Qualité inćgale do l'impresaion

Inclitea supplementary material/

Comprend du matóriel supplómentaire

Only edition avallabie/

Soule ed!tion diaponible

Pages wholly or partially obscurad by errata slips, tissues, otc., have been refilmed to ensure the beet posaible image/ Les pages totalement ou partiellement obscurcies per un feuillet d'errata, une pelure, etc., ont etté filmbes I nouveau de façon a obtenir la meilleurs imaso possible.

This item is filmed at the reduction ratio checklad below/

Ce document est filmó au taux de réduction indiqué si-dessous.

$10 x$

$14 x$

$18 x$

$22 x$

$26 x$

$30 x$

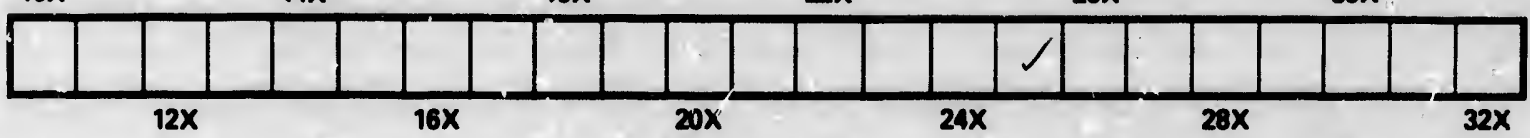


The copy filmed here has been reproduced thanks to the generosity of:

Izaak Waiton Killam Memorial Library

Dalhousie University

The imazes appecring here are the best quality possible considering the condition and legibility of the original copy and in keeping with the filming contract specifications.

Original copies in printed paper covers are filmed beginning with the front cover and ending on the last page with a printed or illustrated impression, or the back cover when appropriate. All other original copies are filmed beginning on the first page with a printed or illustrated impression, and ending on the last page with a printed or illustrated impression.

The last recorded frarne on each microfiche shall contain the symbol $\longrightarrow$ (meaning "CON. TINUED"), or the symbol $\nabla$ (meaning "END"). whichever applies.

Map8, plates, charts, etc., may be filmed at different reduction ratios. Those too large to be entirely included in one exposure are filmed beginning in the upper loft hand corner, left to right and top to bottom, as many frames as required. The following diagrams illustrate the method:
L'exemplaire filmé fut reproduit grâce a la gónérosité de:

Izaak Walton Killam Memorial Library Dalhousie University

Les images suivantes ont été reproduites avec le plus grand soin, compte tenu de la sondition et de la netteté de l'exemplaire filme, et en conformité avec les conditions du contrat de filmage.

Les exemplaires originaux dont la couverture en papier est imprimée sont flimés en commençant par le premier plat et en terminant soit par la derniére page qui comporte une empreinte d'inpression ou d'illustration, soit par lo second plat, selon le cas. Tous las autres exemplaires originaux sont filmés en commençant par la première page qui comporte une empreinte d'impression ous d'illustration et en terminant par la dernière page qui compo:te une tolle umpreinte.

Un des symboles suivants apparaîtra sur la dernière image de chaque microficho, selon le cas: Ie symbole $\rightarrow$ signifie "A SUIVRE", le symbole $\nabla$ signifie "Fin".

Les cartes, planches, tableaux, etc., peuvent être filmés à des taux de réduction différents. Lorsque le document est trop grand pour etre reproduit en un seul clichs, il est filmé a partir de l'angle supérieur gauche, de gauche a droite, ot de haut en bas, on prenant le nombre d'imagas nécessaire. Les diagrammes suivunts illustrent la méthode.

\begin{tabular}{|l|l|l|}
\hline 1 & 2 & 3 \\
\hline
\end{tabular}
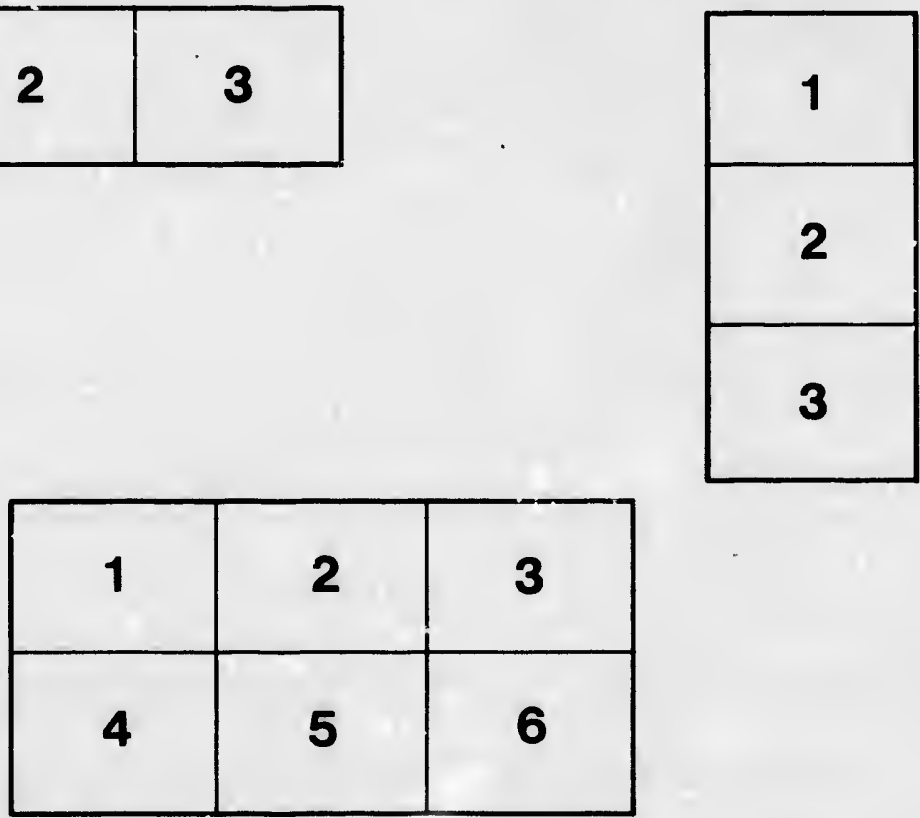


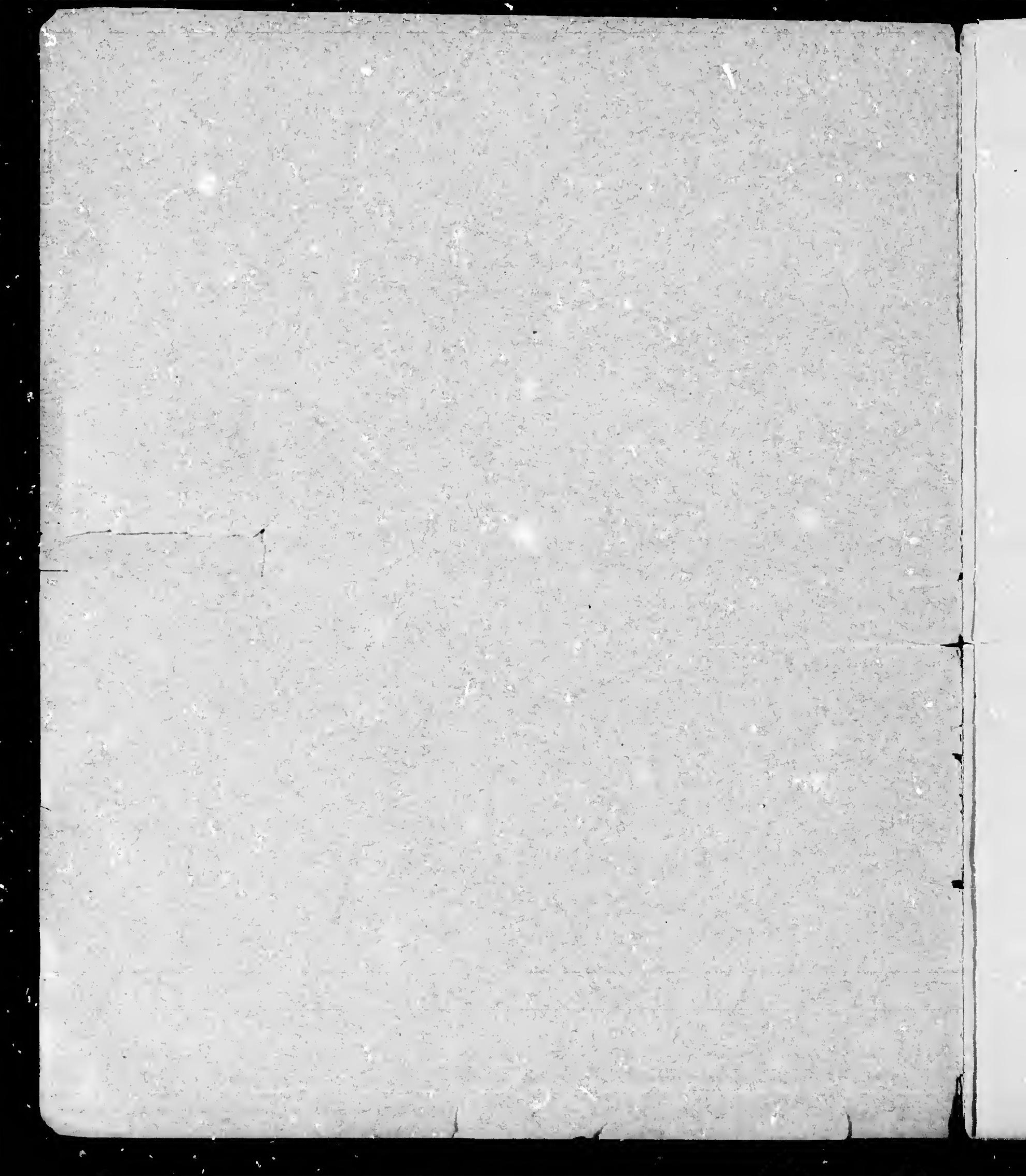




\title{
II.-On the Present State of Botany in Canadu, with suggestions as to promising lines of investigation., and a proposal for united effort in systematic observation throughout the several Provinces and Territories.
}

\author{
By Georae Lawson, PhD., LL.D., F.I.C.
}

(Read May 27, 1891.)

At the present time, botanieal researeh in Canada depends largely upon voluntary service. Even the teaching of Botany of our colleges and universities is left too much to professors overburdened with other duties. The work of research may be allocated to distinet departments. First, we have the investigation of the minute strueture of the plant, the forms and modifications of its tissue elements, their modes of development, and, generally, those phenomena that are directly traceable to the action in the living plant of the grannlar semi-fluid which Hugo von Mohl, nearly sixty years ago, ealled "protoplasm," and was content to regard as simply primordial organie substance concerned in the proresses of cell-development.

Research in this department requires eareful training on the part of the student in the use of the mieroseope and its adjunets, in stainings and other methods now commonly employed to canse the tissue elements to reveal their intimate textures, and in the application of chemieal tests to diselose the suecessire ehanges in the nature of the celi contents, of the compounds associated with and separable from the protoplasm in the processes of growth, and of the varions substances that become secreted or separated from the crdinary active cell-sap, and collect, either in special receptacular cells, or in intereellular glindular cavities, or are poured out on the surface.

We have also the study of plant organs, formed by the association and union of the tissues into anatomical forms, the physiological actio as of such organs, and, specially, the effeets of heat, light, moisture, soil-constituents, and other external agencies in relation thereto, as well as on the plant's activities in general.

Notwithstauding all that has already been done, there is still ample room for researeh in regard to the process of assimilation, or appropriation of inorganic matter, and its transformation into organie substanee, - two obvionsly distinct processes that eannot, with our present knowledge, be elearly separated.

The series of ehanges which the organic matter once formed afterwards undergoes, that is, its subsequent transmutation or metastasis, now known as metabolism, whereby new and remarkable compounds are produced, is a subject of no less interest, either from a physiologieal or chemical point of riew ; and, inasmuch as its effeetive study is so recent, it offers a frstiie field in which only detached natehes have been cultivated.

The subject of the movements of plants, or rather of their organs, needs only to be mentioned to recall observations already recorded suggestive of the interest pertaining to many that still remain to be made.

$$
\text { Sec. IV, 1891. } 3 .
$$

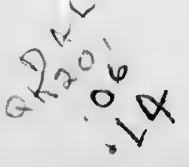


As regards the remarkably multifarious, yet correlative, processes of reproduction in the vegetable kingdom, their phrnomena have been steadily under investigation, with constantly increasing improrement of apparatus and appliances, for half a century, and the interest and wealth of results only increase with the years.

Investigation of the subjects to which I have thus briefly alluded can be undertaken, with reasonable prospect of success, only by those who have enjoyed preliminary training in the more recent modes of investigation, and in the nse of the varied forms of apparatus that have been designed to enable observations and experiments to be made with the nearest possible approach to precision. Fortunately, the efforts of our higher educational institutions, not only the miversities and professional schools, but high schools and academies, and also some of our agricultural establishments, colleges and experimental stations, are now being put forth, with fair show of success, to neet the wants of botanical students. Where eren a preiminary training only in manipulation: is obtained, zeal, energy and perseverance may do the rest.

From what has been stated, it will be obvious that efforts to extend our knowledge in the departments enumerated will depend to a very large extent upon the practical loboratory teaching at the universities and other public institutions throughout the sev. eral provinces. Where this is provided researches will be undertaken by special and graduate students. This kind of university work is the crowning fruit of his teaching that rewards a professor's labours. Every effort should be made to encourage such students to continue their work after leaving college, otherwise the labour spent in college, while of educational value to the individual, may be lost so fur as the interests of science are concerned. This remark may not be thought entirely out of place when I mention that a friend told me within the last few days that on a recent revisit to Germany, Dr. Strasburger, the well-known veg'etable physiologist, in whose laboratory he had worked in former years, expressed, not his delight only, but his surprise, that his American pupil had really continued to go on with his microscopical work after returning to his American home.

What I have said in regard to research in the minute anat smy and physiology of plints generally will apply, to a large extent, to an allied depariment of a still mnre special character, viz., fossil botany, which, through the indefatigable labours and admirable researches extending over so many years of Sir Williain Dawson and latterly of Dr. Penhallow, has been so prominent in the publications of the Royal Society of Canada as to command attention to our publication wherever the subject is studied, and attention to the subject wherever our publication reaches.

After receiving proper training in methods of observation and in the mechanical processes of preparing specinens, the physiological and the paloontological botanists may c atinue to pursue their work at home almost single-handed. It is not so with the systematic or species botanist. $\mathrm{He}$ is continually in need of the assistance of others in multifarious ways, and, whether monographing a family, investigating the relations of a puzzling species, or tabulating facts for a speculation in geographical botany, he must have constant recourse to the observations, collections, libraries and advice of others.

While, thell, the increasud facilities that are being provided at our universities, or some of them, for the pursuit of the lines of research embraced under the still expressive terms anatemy and physiology of plants, may be expected to lead to adrancement hitherto 
unexampled, it is also to be feared that the direction thus given to the studies of college students will tend to lessen rather than increaso their attention to field, or what is perhaps best known on this continent is systematic or species botany.

The energies of our ec ge students and graduates will thus, in the future, be withdrawn, not wholly, it is hoped, but neessarily to some extent, from the mere work of collecting and naming specimens (in itself a valuable educational exereise), and from the practical study of botanical elassification and the diagnostic characters of the genera and species of Canadian plants. We may still rely upon an increasing number of amateur workers throughout the country, persons of leisure, and even men laden with professional duties, who, while seeking a well-earned week's rest in a rural distriet, may tire of admiring beauties of field and wood, as if Nature offered a mere dumb show, and perehance turn even to botany books for some whisper of the language she speaks.

We have now a comparatively new, but rapidly increasing, source of botanical power in the large army of school teachers and their pupils in our academies and common sehools throughout the conntry, botany being taught more or less fully in most of the provinces. They may well take up the work dropped by college students.

The collecting of facts, the fiuding of rare plants, the noting of the occurrence or absence of species in given districts, the recording of their times of leafing, flowering and fruiting, can best be done by residents in the several localities, and, if we could succeed in banding together the edusational fores of the country for this purpose, even to a partial extent, immense service might be rendered to our science with the subsidiary advantage of increasing its popularity by giving a large number who at present do not aspire to be bntanists some lot or part in its promotion. I am not unmindful of the excellent work that is being done, often in an unostentatious manner, by local societies, signally prominent among which, as a thorough working botanieal society, we must place the Natural History Society of Ottawa. But the work now being done by such organizations may be largely aided and supplemented by a more general effort.

One great want of Canadian botanists is some easy chamne1 of communication with each other. We have no society, and no publication, that will take cognizance of the local lists and scraps of observation that go to make up botanical periodicals so largely and that prove such fertile material in the hands of the botanical worker. There can be no doubt that the progress of botany in Britain during the present century has been largely due to the facilities of publication offered to even the humblest observers by such publications as Loudon's 'Magazine of Natural History,' the London 'Gardeners' Chronicle,' 'The Phytologist,' of Newman, the short-lived 'Botanical Gazette,' of Henfrey, 'Seeman's Journal,' the 'London Journal of Botany,' and other open records, of which everyone could avail himself for the purposes of giving or receiving information. But we have had no such publication in Canada. Thirty years ago an attempt was made to supply this want of our country by issue of the 'Anuals of the Botanical Society of Canada.' That publication, during its brief existence, was chiefly remarkable for its local lists of plants, forbidding and unreadable to all but botanical students. Yet these lists gave it a certain permanent value that caused it to be eagerly sought for long after it was out of print. In the United States we have two ably conducted botanical periodicals, and others in Fngland and continental Europe. All of these may be more or less available to Canadian botanists, but we are not able through any of them to be sure that we are really 
bringing our facts within reach of our own fellow-countrymen, to whom they will be most useful. For the printing of the more finished elass of papers, the publications of the numerous local scientifie societies in Canada, now happily assoeiated with the Royal, give opportunity, and the volumes of 'Transactions of the Royal Society' itself form the proper repository for such treatises as, by their elaboration or requirements of illustration, extend beyond the capabilities of the local societies. However, mere local lists, scraps, accounts of botanical excursions, nnless they are marked by literury merit, or some feature extraneons to the mere record of botanical facts, cannot be expected to be acceptable to any of onr existing publications, and thus the valuable facts which they embrace are apt to be lost to science.

It is with the riew of suggesting the propriety of adopting some means for advantageously meeting the wants, whose existence I merely require to indicate rather than explain, that I have taken the liberty of now asking the attention of this section of the Royal Society. I do not propose that a botanical periodical shall be established. I hope, however, that some method may be devised whereby inmediate publication of every season's botanical field obserrations throughout Canadi may be seeured. The eompletion of Prof. Macoun's grwat work, the "Catalogue of Canadian Plants," in which the working botanists of Canada have now a valuable guide, seems to be a fitting time for derising some suitable scheme.

My proposal, or suggestion rather, in brief, then is, not that the Royal Society shall take any action or new responsibility, nor that this section shall do so, but that its botanical members, and those who desire to associate themselves with them, shall form an organization of the simplest possible kind, for securing such of the results referred to as it may be thought wise to attempt,-to organize a band of gleaners, as it were, following as far as practicable the model of the old Berwickshire Naturalists' Field Club of Scotland, that did really good work under the admirably simple constitution that it should have no rules, no by-laws, no officers, no restraint of any kind, but the implied marching order that, on their field days, the members would voluntarily follow their leader as far as their own individual wills or inclinations might lead them. Onr organization would possibly require some bond of union a little stronger than this. I forbear, however, to make any suggestion, even in that regard, further than to say that, if the botanical members of this section will agree to undertake the task and duties of local seeretaries in their respective localities of some such prospective organization, a nuclens can be formed which may in time extend into an army of explorers pervading the whole extent of our Dominion. Each local secretary can, in his locality, direct the stream of local ohservations into the general channel, and thus secure valuable records or material that would otherwise pe lost, and within his own range assist and encourage young workers in the many ways known to a botanist. Meetings of all the members of such a widespread organization could never be held at any one point, but it might be practicable, once a year, when we come up to the Royal Society's annual gatherings, for many of the local secretaries and other nuclear elements, to hold a conference, as is usual with similar clubs and offshoots of, for example, the British Ascosiation,-one of which, the old Ray Society, resembled in organization, although not in purpose, very much what is now proposed. But I am more anxious to hear the suggestions of my fellow members in this section on the points mooted than to put forth any more definite scheme. 

